\title{
HERBICIDAL POTENTIAL OF LANTANA CAMARA L. ON LUDWIGIA SPP IN PADDY SOIL
}

Sudheera MW Ranwala*, LR Attigala and Shwetha de Silva

Department of Plant Sciences, Faculty of Science, University of Colombo, PO Box 1490, Colombo, Sri Lanka

Accepted: $12^{\text {th }}$ August 2014

\begin{abstract}
This study assessed herbicidal potential of Lantana (Lantana camara L.), on two commonly found paddy field weeds; Ludwigia decurrens Walt. and Ludwigia hyssopifolia (G. Don) Exell. Methodology involved a laboratory bioassay using 1:5 w/v and 1:10 w/v aqueous Lantana dried leaf extracts to assess germination, cotyledon expansion, root and shoot development of Ludwigia spp. Green house experiments included paddy soil amendments using $1 \mathrm{~g}, 2 \mathrm{~g}, 4 \mathrm{~g}$ dried Lantana leaf residues in $85 \mathrm{~g}$ soil and $30 \mathrm{~g}, 60 \mathrm{~g}, 120 \mathrm{~g}$ residues in $2.5 \mathrm{~kg}$ paddy soil respectively to test seedling establishment and growth of Ludwigia spp. Toxicity of Lantana on rice (Oryza sativa) was tested by growing rice cv. 'BG 353' with $L$. decurrens in Lantana amended paddy soil. Toxic effects of Lantana on naturally occurring micro-biota were also assessed by diffusion method using $1.5 \mathrm{w} / \mathrm{v}$ Lantana dried leaf extracts on pure cultures of fungi and bacteria isolated from paddy soil. Results indicated that 1:5 w/v was the strongest extract to suppress root and shoot development of seedlings of both weeds. An amount of $4 \mathrm{~g}$ Lantana leaf residue in 85g paddy soil suppressed germination and seedling establishment of $L$. hyssopifolia while higher quantities such as $120 \mathrm{~g}$ of dried Lantana leaf residues in 2.5 paddy soil was required to suppress growth of $L$. decurrens. No potential harmful effects of Lantana were observed on growth of rice seedlings and microbiota of paddy soil. Higher quantities such as $120 \mathrm{~g}$ in $\mathbf{2 . 5}$ paddy soil were required to suppress growth of $L$. decurrens.
\end{abstract}

Key words: Allelopathy, Herbicidal - potential, Lantana, Ludwigia, Phytotoxicity

\section{INTRODUCTION}

Allelochemicals are partly responsible for the impressive success of alien invaders in nonnative environments, thus considered as 'chemical weapons' (Hierro and Callaway, 2003, Kim and Lee, 2011, Ni et al. 2012). The common Lantana, Lantana camara L., (family: Verbenaceae), listed among the world's hundred worst invasive alien species (IUCN, 2001) is reported to cause substantial ecological and economic losses to agriculture and biodiversity in many countries (Holm et al. 1979, Swarbrick et al. 1998, Gooden et al. 2009). It contains mono, tri and sesquiterpenes including Lantadene A and B, iridoid and phenyl ethanoid glycosides, flavonoids as allelochemicals (Ghisalberti, 2000) that have shown promising toxic effects on many plant species such as Morrenia odorata Lindl. (Achhireddy and Singh, 1984), Lemna paucicostata Hegelm (Sutton and Potier 1989), Eichhornia crassipes
(Mart). Solms. (Zhang et al. 2005), Commmelina benghalensis L., Echinocloa colonum (L.) Link., Digitaria sanguinalis (L.) Scop, Panicum psilopodium Trin. (Bansal, 1998), Microcystis aeruginosa (Kong et al. 2006), Abutilon theophrasti Medik., Lepidium virginicum L. (Mersie and Singh, 1987), Cyclosorus dentatus (Forsk.) Ching. (Wadhawani and Bhardwaja, 1981) and Amaranthus hybridus L. (Verdeguer et al. 2009). Hence, allelopathic properties of plant invaders could be positively manipulated to maintain ecological sustenance of agricultural systems (Prasad, 1998, Qasem and Foy, 2001, Xuan et al. 2005, Narwal, 2010). It has been a common indigenous practice to use of Lantana camara leaf residues (either alone or together with other plant debris) in traditional farming systems in India (CSIR 1966), Kenya (WAC 1995, Roothaert and Franzel, 2001) and Sri Lanka (Ranganath 1993). 
Such usage also provide opportunities to control populations and manage the spread of alien plant invaders at a minimum cost (Saha et al. 2007).

The present work aims to explore further the herbicidal properties of Lantana camara (Lantana) by describing toxic effects produced by aqueous leaf extracts and dried leaf residues on seed germination, cotyledon expansion, seedling establishment and growth of two noxious broad leaved paddy field weeds Ludwigia decurrens Walt. and Ludwigia hyssopifolia (G. Don) Exell., that prevail in wet lowland paddy fields of South East Asia including Sri Lanka (Chandrasena 1988). Investigations also included identification of any potential harmful effects of Lantana on a popular low country grown direct- seeded rice cultivar (Oryza sativa cv. 'BG 353') and naturally occurring bacteria and fungi species found in herbicide free paddy soil obtained from fields of Borelesgamuwa area of the Western Province, Sri Lanka.

\section{MATERIALS AND METHODS}

\section{Germination and seedling development of Ludwigia spp exposed to Lantana leaf ex- tracts}

According to preliminary laboratory trials, weights of $200 \mathrm{~g}$ and $100 \mathrm{~g}$ of air dried mature Lantana leaves each were soaked in $1000 \mathrm{ml}$ distilled water at $10^{\circ} \mathrm{C}$ for 7 days and 1:5 (w/v) and 1:10 (w/v) aqueous filterates were obtained. Half of each solution was boiled under a Bunsen gas flame for 5 minutes to identify any changes of the filterate. More than two thousand L. decurrens and L. hyssopifilia seeds were hand picked from mature capsules, rinsed under running tap water in muslin bags for twenty minutes and blotted dried. Seeds were placed (10 per Petri plate) on dry filter paper (No. 1 Whatmann International, Maidstone UK) lined on $9 \mathrm{~cm}$ diameter glass Petri plates. The experiment was conducted according to a completely randomized design with 20 replicates at $30 \pm 1{ }^{0} \mathrm{C}$ under $12 \mathrm{~h}$ day- length conditions. Seeds were subjected to treatments
(1:10 boiled extract, 1:10 unboiled extract, 1:5 boiled and 1:5 unboiled extracts) by moistening the filter papers daily with an equal volume of appropriate solutions. Seeds treated with distilled water were used as the control. Seed germination (radicle length of $\geq 2 \mathrm{~mm}$ ) was recorded until no germination was observed for three consecutive days. Lengths of shoots and roots of the germinated seedlings were measured and the number of seedlings with expanded cotyledons was recorded on the $19^{\text {th }}$ day after germination.

\section{Germination and/or seedling emergence of Ludwigia spp in paddy soil amended with Lantana leaf residues}

Germination of Ludwigia seeds in paddy soil containing different quantities of Lantana leaf residues was monitored in a greenhouse at $29 \pm 1{ }^{0} \mathrm{C}$ under $12 \mathrm{~h}$ day length conditions. Dried Lantana leaf residues weighing $1 \mathrm{~g}, 2 \mathrm{~g}$ and $4 \mathrm{~g}$ were each mixed with $85 \mathrm{~g}$ of pesticide free paddy soil (sandy loam in texture, $\mathrm{pH}$ 5.14 at 1:25 water, Organic matter $1.3 \%$, Oslens's Phosphorous $6.5 \mathrm{ppm}$ ) in plastic pots (65 $\mathrm{mm}$ in diameter and $35 \mathrm{~mm}$ in height) to obtain different soil residue combinations. The ratio of residue: soil has been chosen in previous experiments (Madushani and Ranwala, 2004, Chaturani and Ranwala, 2005). Each pot had 10 weed seeds of either species. Controls contained paddy soil without Lantana residues. Another set of pots containing Lantana residues was kept without seeds of test species to monitor the seedling establishment of the existing seed bank of paddy soil. Pots were arranged in completely randomized design with 10 replicates and kept moist throughout. Emergence of seedlings from introduced seeds of test species and paddy soil seed bank was monitored for 22 days.

\section{Growth of $\boldsymbol{L}$. decurrens seedlings in leaf resi- due amended paddy soil (with or without rice plants)}

The experiment was designed to monitor the growth of $L$. decurrens which was able to establish seedlings in soil containing dried Lan- 
tana leaf residues. Here too, the ratio of residue: soil was maintained as same above but higher quantities of materials were used. Thus, Lantana leaf residues weighing $30 \mathrm{~g}, 60$ $\mathrm{g}$ and $120 \mathrm{~g}$ were each mixed with $2.5 \mathrm{~kg}$ of paddy soil in a total of 50 pots $(380 \mathrm{~mm}$ in diameter and $120 \mathrm{~mm}$ in height). The control contained paddy soil without Lantana residues. To each pot, five 4 week old $L$. decurrens seedlings (raised in trays in green house conditions up to an approximately $5 \mathrm{~cm}$ height) were introduced. Each treatment was replicated ten times. Pots were arranged in completely randomized design and plants were kept moist throughout. Plant height and leaves per plant was recorded for $L$. decurrens seedlings weekly for six weeks (so as to be equivalent with critical period of rice) and the total dry weight was obtained. The same methodology was followed for $L$. decurrens grown in pots (five 4 week old weed seedlings) with one 2 week old rice plant of the same height (raised in trays in green house conditions) belonging to cultivar 'BG 353', one of the popular cultivars used for directseeded rice cultivations in wet lowlands of Sri Lanka. Additionally, plant height, leaves per plant and biomass of rice seedlings was also measured at the end of six weeks to identify any toxic effects of Lantana on growth of rice.

\section{Effects of Lantana on bacteria and fungi of paddy soil}

For isolation of naturally occurring fungi and bacteria, a dilution series of paddy soil suspensions was prepared and $0.1 \mathrm{~mL}$ aliquots of $10^{-1}, 10^{-2}, 10^{-3}, 10^{-4}$ and $10^{-5}$ dilutions were introduced separately to sterile Potato Dextrose Agar (PDA) and Nutrient agar (NA) media supplemented with Tetracyclin $(3 \mu \mathrm{L} / \mathrm{mL})$ and Chloramphenicol $(1 \mu \mathrm{L} / \mathrm{mL})$ respectively. The $\mathrm{pH}$ was adjusted to 5.14 and incubated at $37^{\circ} \mathrm{C}$ for 7 days. The fungi were purified at $37^{\circ} \mathrm{C}$ on sterile PDA slants while bacteria were isolated in standard nutrient broths (Carter \& Gregorich, 2007) and separately stored at $37^{\circ} \mathrm{C}$. Culture collections of bacte- rial (Streptococcus sp., Staphylococcus sp and Bacillus sp.) and fungal (Aspergillus sp., Trichoderma sp. and Fusarium sp.) obtained from the Department of Plant Sciences, University of Colombo were used as references. Unboiled Lantana (dried) leaf extract (1: $5 \mathrm{w} /$ v) was introduced to bacterial and fungal cultures containing 5 replicates each. Well diffusion method was used for bacteria cultured on NA as described by Booth (1971). Petri plates were incubated at $37^{\circ} \mathrm{C}$ for $20 \mathrm{hrs}$. Disc diffusion method (Murray et al. 1995) was used to assess toxicity on soil fungi incubated at $30 \pm 1^{\circ} \mathrm{C}$ for $72 \mathrm{~h}$. Appearance of clear inhibition zones on NA and PDA plates in the presence of $L$. camara extract was considered as a toxic effect produced by Lantana.

All data sets were separately subjected to Analysis of Variance (ANOVA) using software SPSS (version 10) and the significance among treatments was tested using Least Significant Difference (LSD) at 0.05 probability level.

\section{RESULTS}

Effect of Lantana leaf extract on germination and seedling development of Ludwigia spp.

Germination, cotyledon expansion, elongation of roots and shoot growth of Ludwigia spp. varied between boiled and unboiled Lantana extracts and of the test species.

The Final Germination Percentage (FGP) of L. decurrens was significantly increased when seeds were in contact with Lantana leaf extract while germination of $L$. hyssopifolia seeds depended upon the strength of the Lantana extract of the medium. A higher strength $(1: 5)$ of Lantana extract significantly $(\mathrm{P}<0.05)$ inhibited germination (the boiled extract showing a greater inhibition) and the lower strength (1:10) stimulated germination indicating a higher FGP over the control. 
Table 1. Final Germination Percentage of $L$. decurrens and $L$. hyssopifolia seeds and Percentage cotyledon expansion, root and shoot lengths of $L$. decurrens and $L$. hyssopifolia seedlings exposed to aqueous Lantana leaf extract under laboratory conditions. Values are means of 20 replicates. Standard errors are given in parentheses at $\mathbf{P}<0.5$ level.

\begin{tabular}{|c|c|c|c|c|c|c|c|c|}
\hline \multirow{2}{*}{$\begin{array}{l}\text { Treatment } \\
\text { (Lantana } \\
\text { extract) }\end{array}$} & \multirow{2}{*}{\multicolumn{2}{|c|}{$\begin{array}{c}\text { Final Germination Per- } \\
\text { centage } \\
\text { L. decurrens L. hyssopifolia }\end{array}$}} & \multicolumn{2}{|c|}{$\begin{array}{l}\text { Percentage of seedlings with } \\
\text { expanded cotyledons }\end{array}$} & \multicolumn{2}{|c|}{ Average root length $(\mathrm{mm})$} & \multicolumn{2}{|c|}{ Average shoot length(mm) } \\
\hline & & & L. decurrens & L. hyssopifolia & L.decurrens & L. hyssopifolia & L. decurrens & L. hyssopifolia \\
\hline Control & $\begin{array}{l}29.00^{\mathrm{x}, \mathrm{p}} \\
( \pm 0.40)\end{array}$ & $\begin{array}{r}68.00^{\mathrm{x}, \mathrm{p}} \\
( \pm 0.37)\end{array}$ & $\begin{array}{l}24.50^{\mathrm{x}, \mathrm{p}} \\
( \pm 0.32)\end{array}$ & $\begin{array}{c}64.00^{\mathrm{x}, \mathrm{p}} \\
( \pm 0.87)\end{array}$ & $\begin{array}{l}03.13^{\mathrm{x}, \mathrm{p}} \\
( \pm 0.03)\end{array}$ & $\begin{array}{l}23.2^{\mathrm{x}, \mathrm{p}} \\
( \pm 0.21)\end{array}$ & $\begin{array}{l}03.99^{\mathrm{x}, \mathrm{p}} \\
( \pm 0.003)\end{array}$ & $\begin{array}{r}37.30^{\mathrm{x}, \mathrm{p}} \\
( \pm 0.31)\end{array}$ \\
\hline $\begin{array}{l}1: 10 \text { Un- } \\
\text { boiled }\end{array}$ & $\begin{array}{l}47.00^{\mathrm{y}, \mathrm{q}} \\
( \pm 0.56)\end{array}$ & $\begin{array}{c}88.00^{\mathrm{y}, \mathrm{q}} \\
( \pm 0.27)\end{array}$ & $\begin{array}{c}31.50^{\mathrm{x}, \mathrm{q}} \\
( \pm 0.53)\end{array}$ & $\begin{array}{l}64.50^{\mathrm{x}, \mathrm{q}} \\
( \pm 0.49)\end{array}$ & $\begin{array}{l}00.14^{\mathrm{y}, \mathrm{q}} \\
( \pm 0.008)\end{array}$ & $\begin{array}{r}07.60^{\mathrm{y}, \mathrm{q}} \\
( \pm 0.02)\end{array}$ & $\begin{array}{l}03.07^{\mathrm{y}, \mathrm{q}} \\
( \pm 0.02)\end{array}$ & $\begin{array}{r}30.00^{\mathrm{y}, \mathrm{q}} \\
( \pm 0.11)\end{array}$ \\
\hline $\begin{array}{l}1: 10 \\
\text { Boiled }\end{array}$ & $\begin{array}{l}40.50^{\mathrm{y}, \mathrm{q}} \\
( \pm 0.39)\end{array}$ & $\begin{array}{c}81.00^{\mathrm{y}, \mathrm{q}} \\
( \pm 0.28)\end{array}$ & $\begin{array}{l}16.00^{\mathrm{x}, \mathrm{q}} \\
( \pm 0.33)\end{array}$ & $\begin{array}{c}56.50^{\mathrm{x}, \mathrm{q}} \\
( \pm 0.54)\end{array}$ & $\begin{array}{l}00.09^{\mathrm{y}, \mathrm{q}} \\
( \pm 0.006)\end{array}$ & $\begin{array}{c}05.40^{\mathrm{y}, \mathrm{q}} \\
( \pm 0.01)\end{array}$ & $\begin{array}{l}02.59^{\mathrm{y}, \mathrm{q}} \\
( \pm 0.01)\end{array}$ & $\begin{array}{c}17.80^{\mathrm{y}, \mathrm{q}} \\
( \pm 0.07)\end{array}$ \\
\hline $\begin{array}{l}\text { 1:5 Un- } \\
\text { boiled }\end{array}$ & $\begin{array}{l}41.00^{\mathrm{y}, \mathrm{q}} \\
( \pm 0.40)\end{array}$ & $\begin{array}{l}50.00^{\mathrm{z}, \mathrm{q}} \\
( \pm 0.39)\end{array}$ & $\begin{array}{c}25.00^{\mathrm{x}, \mathrm{q}} \\
( \pm 0.14)\end{array}$ & $\begin{array}{c}00.50^{\mathrm{y}, \mathrm{q}} \\
( \pm 0.05)\end{array}$ & $\begin{array}{l}01.05^{\mathrm{z}, \mathrm{q}} \\
( \pm 0.004)\end{array}$ & $\begin{array}{r}03.10^{\mathrm{y}, \mathrm{q}} \\
( \pm 0.02)\end{array}$ & $\begin{array}{l}00.00^{\mathrm{z}, \mathrm{q}} \\
( \pm 0.00)\end{array}$ & $\begin{array}{c}12.40^{\mathrm{z}, \mathrm{q}} \\
( \pm 0.06)\end{array}$ \\
\hline 1:5 Boiled & $\begin{array}{l}38.00^{\mathrm{y}, \mathrm{q}} \\
( \pm 0.46)\end{array}$ & $\begin{array}{l}30.50^{\mathrm{z}, \mathrm{r}} \\
( \pm 0.39)\end{array}$ & $\begin{array}{l}0.00^{\mathrm{z}, \mathrm{q}} \\
( \pm 0.00)\end{array}$ & $\begin{array}{l}00.50^{\mathrm{y}, \mathrm{q}} \\
( \pm 0.05)\end{array}$ & $\begin{array}{l}01.21^{\mathrm{z}, \mathrm{q}} \\
( \pm 0.005)\end{array}$ & $\begin{array}{r}06.00^{\mathrm{y}, \mathrm{q}} \\
( \pm 0.02)\end{array}$ & $\begin{array}{l}00.00^{z, q} \\
( \pm 0.00)\end{array}$ & $\begin{array}{l}04.90^{\mathrm{z}, \mathrm{q}} \\
( \pm 0.02)\end{array}$ \\
\hline
\end{tabular}

Superscripts ${ }^{\mathrm{x}, \mathrm{y}, \mathrm{z}}$ and ${ }^{\mathrm{p}, \mathrm{q}, \mathrm{r}}$ in a column show significance between concentrations and boiled- unboiled nature of the extract respectively at $\mathrm{P} \leq 0.05$ significant level

Further contact of germinated Ludwigia seeds with Lantana extract affected cotyledon expansion of young seedlings. The boiled higher strength (1:5) was much effective in inhibiting expansion of cotyledons in both Ludwigia spp while the unboiled extract of the same strength inhibited cotyledon expansion only in L. hyssopifolia. Boiling of the Lantana extract had no effect on elongation of roots and shoots. Nevertheless, higher strength of the Lantana extract produced significant suppressive effects on shoot growth than root growth of young Ludwigia seedlings (Table 1).

\section{Effect of Lantana leaf residues on seedling emergence of Ludwigia spp.}

Seedling emergence of $L$. decurrens was not affected due to the addition of Lantana residues to paddy soil while that of L. hyssopifolia seeds showed a significant suppression when residues were added over and above $2 \mathrm{~g}$ per $85 \mathrm{~g}$ to paddy soil. Seedling emergence of monocotyledon and dicotyledon weeds from the existing seed bank of paddy soil showed a decreasing trend with increasing weights of $L$. camara residues (Table 2).
Table 2. Seedling emergence of $L$. decurrens, $L$. hyssopifolia and associated other weeds exposed to different weights of Lantana residue in soil under glasshouse conditions. Values are means of 20 replicates. Standard errors are given in parentheses at $\mathbf{P}<0.5$ level.

\begin{tabular}{|c|c|c|c|c|}
\hline \multirow{2}{*}{$\begin{array}{l}\text { Seedling } \\
\text { emergence }\end{array}$} & \multicolumn{4}{|c|}{ Lantana Leaf Residue in paddy soil (g) } \\
\hline & Control & 1 & 2 & 4 \\
\hline $\begin{array}{l}\text { L. decurrens } \\
\text { (\%) }\end{array}$ & $\begin{array}{l}40.00^{x} \\
( \pm 0.47)\end{array}$ & $\begin{array}{l}47.00^{\mathrm{x}} \\
( \pm 0.67)\end{array}$ & $\begin{array}{l}59.00^{x} \\
( \pm 0.91)\end{array}$ & $\begin{array}{l}57.00^{x} \\
( \pm 0.63)\end{array}$ \\
\hline $\begin{array}{l}\text { L. hyssopifolia } \\
\text { (\%) }\end{array}$ & $\begin{array}{l}90.00^{\mathrm{x}} \\
( \pm 0.47)\end{array}$ & $\begin{array}{l}85.00^{\mathrm{x}} \\
( \pm 0.50)\end{array}$ & $\begin{array}{l}47.00^{y} \\
( \pm 0.76)\end{array}$ & $\begin{array}{l}11.00^{\mathrm{z}} \\
( \pm 0.38)\end{array}$ \\
\hline $\begin{array}{l}\text { Monocotyledon } \\
\text { seedlings }\end{array}$ & $\begin{array}{r}35.67^{x} \\
( \pm 0.38)\end{array}$ & $\begin{array}{l}42.83^{\mathrm{x}} \\
( \pm 0.42)\end{array}$ & $\begin{array}{l}29.50^{y} \\
( \pm 0.23)\end{array}$ & $\begin{array}{l}17.33^{\mathrm{z}} \\
( \pm 0.17)\end{array}$ \\
\hline $\begin{array}{l}\text { Dicotyledon } \\
\text { seedlings }\end{array}$ & $\begin{array}{l}43.50^{\mathrm{x}} \\
( \pm 0.47)\end{array}$ & $\begin{array}{l}27.17^{\mathrm{x}} \\
( \pm 0.40)\end{array}$ & $\begin{array}{l}15.33^{\mathrm{x}} \\
( \pm 0.20)\end{array}$ & $\begin{array}{l}09.17^{\mathrm{y}} \\
( \pm 0.15)\end{array}$ \\
\hline
\end{tabular}

Superscripts $^{x, y, z}$ in a row indicate significance between treatments at $\mathrm{P} \leq 0.05$ significant level

Effect of Lantana residues on growth of $L$. decurrens seedlings grown with or without rice

Although $L$. decurrens seedlings were able to survive in a paddy soil growing medium containing Lantana leaf resides, their growth, in terms of height, leaf and biomass production was significantly decreased when a higher weight of Lantana residues $(60 \mathrm{~g}$ and $120 \mathrm{~g})$ were mixed with paddy soil. 
However presence of the rice plants in the growing medium favoured growth of $L$. decurrens rather grown alone. There was no change in leaf production and biomass of rice plants grown with $L$. decurrens in a medium containing different weights of Lantana resides (Table 3, Figures 1and 2).

\section{Effect of Lantana on bacteria and fungi in paddy soil}

Pure cultures of two soil bacteria and three soil fungi were isolated from paddy soil. No clear inhibition zones were observed in any of these species when L. camara leaf extract was in contact with the microbes. The observations were same with known bacteria: Streptococcus sp., Staphylococcus sp. and Bacillus sp. and known fungi: Aspergillus sp., Trichoderma sp. and Fusarium sp. Remarkable antimicrobial activity was recorded only by the antibiotic and antifungal solutions (Table 4).

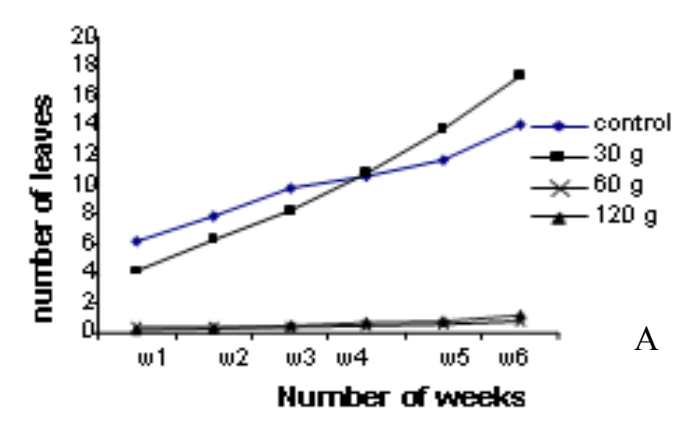

Table 3. Dry weight $L$. decurrens seedlings and growth performance of rice seedlings grown in paddy field soil mixed with different weights of Lantana. Values indicate averages of 6 week old 50 plants for $L$. decurrens and 10 plants for rice. Standard errors are given in parentheses at $P<0.5$ level.

\begin{tabular}{|c|c|c|c|c|}
\hline & \multicolumn{4}{|c|}{ Lantana Leaf Residue in paddy soil (g) } \\
\hline & Control & 30 & & \\
\hline $\begin{array}{l}\text { Dry weight (g) of } \\
\text { L. decurrens } \\
\text { seedlings } \\
\text { grown without rice }\end{array}$ & $\begin{array}{l}0.31^{\mathrm{x}} \\
( \pm 0.07)\end{array}$ & $\begin{array}{l}0.69^{y} \\
( \pm 0.18)\end{array}$ & $\begin{array}{l}0.02^{\mathrm{x}} \\
( \pm 0.02)\end{array}$ & $\begin{array}{c}0.01^{\mathrm{x}} \\
( \pm 0.01)\end{array}$ \\
\hline grown with rice & $\begin{array}{l}1.24^{\mathrm{x}} \\
( \pm 0.03)\end{array}$ & $\begin{array}{l}0.76^{\mathrm{x}} \\
( \pm 0.01)\end{array}$ & $\begin{array}{l}0.28^{\mathrm{y}} \\
( \pm 0.01)\end{array}$ & $\begin{array}{c}0.04^{y^{\prime}} \\
( \pm 0.00)\end{array}$ \\
\hline $\begin{array}{l}\text { Growth perform- } \\
\text { ance of rice seed- } \\
\text { lings }\end{array}$ & & & & \\
\hline $\begin{array}{l}\text { Number of leaves/ } \\
\text { plant }\end{array}$ & $\begin{array}{l}4.10^{\mathrm{x}} \\
\pm 0.18)\end{array}$ & $\begin{array}{l}4.90^{\mathrm{x}} \\
( \pm 0.18)\end{array}$ & $\begin{array}{c}4.80^{\mathrm{x}} \\
( \pm 0.13)\end{array}$ & $\begin{array}{l}4.80^{\mathrm{x}} \\
( \pm 0.13)\end{array}$ \\
\hline Plant height $(\mathrm{cm})$ & $\begin{array}{c}31.85^{\mathrm{x}} \\
( \pm 1.01)\end{array}$ & $\begin{array}{c}31.30^{x} \\
( \pm 1.85)\end{array}$ & $\begin{array}{r}26.20^{x} \\
( \pm 1.09)\end{array}$ & $\begin{array}{r}29.85^{\mathrm{x}} \\
( \pm 0.61)\end{array}$ \\
\hline $\begin{array}{l}\text { Total dry weight } \\
\text { (g) }\end{array}$ & $\begin{array}{l}1.06^{\mathrm{x}} \\
( \pm 0.01)\end{array}$ & $\begin{array}{c}1.21^{\mathrm{x}} \\
( \pm 0.01)\end{array}$ & $\begin{array}{c}0.90^{\mathrm{x}} \\
\pm 0.01)\end{array}$ & $\begin{array}{r}0.97^{\mathrm{x}} \\
( \pm 0.02)\end{array}$ \\
\hline
\end{tabular}

Superscripts $^{\mathrm{x}, \mathrm{y}, \mathrm{z}}$ in a row indicate significance between treatments at $\mathrm{P} \leq 0.05$ significant level

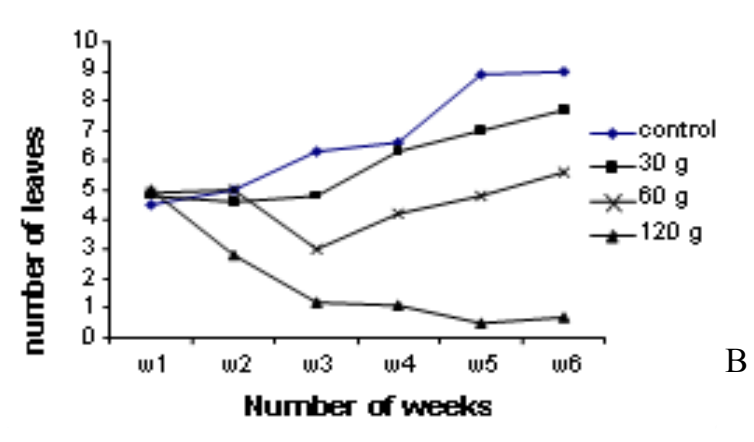

Figure 1. Number of leaves per plant of $L$. decurrens when grown with Lantana leaf residues (A) without rice plants (B) with rice plants. Values indicate averages of 50 plants
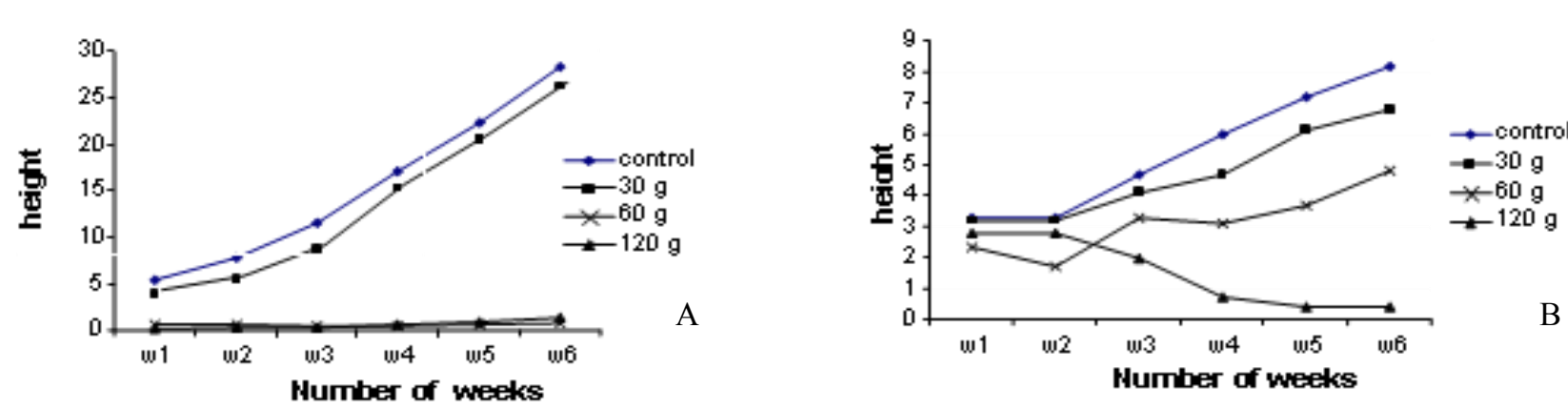

Figure 2. Plant height of $L$. decurrens when grown with Lantana leaf residues (A) without rice plants (B) with rice plants. Values indicate averages of 50 plants. 
Table 4: Effect of L. camara extracts and antibiotic solution (Amocylin 1 $\mathrm{mg} / \mathrm{mL}$ ) on soil bacteria and antifungal solution (Ketoconazole $2 \mathrm{mg} / \mathrm{mL}$ ) on soil fungi

\begin{tabular}{|c|c|c|c|}
\hline \multirow[t]{2}{*}{ Soil microflora } & \multirow[t]{2}{*}{$\begin{array}{l}\text { Amocylin } \\
(1 \mathrm{mg} / \mathrm{mL})\end{array}$} & \multirow[t]{2}{*}{$\begin{array}{l}\text { Ketoconazole } \\
(2 \mathrm{mg} / \mathrm{Ml})\end{array}$} & $\begin{array}{c}\text { Extract from undecomposed } \\
\text { Lantana residues }\end{array}$ \\
\hline & & & $1: 5$ \\
\hline
\end{tabular}

Bacteria species

Isolate 1
Isolate 2
Streptococcus $\mathrm{sp}$
Staphylococcus $\mathrm{sp}$

$\begin{array}{ll}* * * & \text { NA } \\ * * * & \text { NA } \\ * * * & \text { NA } \\ * & \text { NA } \\ * & \text { NA }\end{array}$

Fungal species

Isolate 1

Isolate 2

Isolate 3

Aspergillus sp

Tricoderma $\mathrm{sp}$

Fusarium sp

$\begin{array}{lllll} & * & - & - \\ \text { NA } & * & - & - \\ \text { NA } & - & - & - \\ \text { NA } & * & - & - \\ \text { NA } & * & - & - \\ \text { NA } & * & - & - \\ \text { NA } & & -\end{array}$

Symbols $* * *$ and $*$ indicate high and low sensitivity respectively, - indicates insensitive status and NA, not applicable

\section{DISCUSSION}

Growth suppressive responses of the two Ludwigia species, L. hyssopifolia and L. decurrens to aqueous Lantana leaf extracts and dried residues varied significantly with regard their identity and growth stage at which the treatments were imposed. Our results indicated that allelochemicals of Lantana could enhance seed germination of Ludwigia spp at 1: 5 and $1: 10 \mathrm{w} / \mathrm{v}$ concentrations, but able to completely supress the establishment and growth of L. hyssopifolia seedlings via inhibiting elongation of root and shoots. In comparison, the phytotoxic effect of Lantana on $L$. decurrens was more effective at a later stage during seedling establishment and subsequent growth of seedlings. This indicated that $L$. hyssopifolia was much susceptible to allelopathic effects of Lantana than $L$. decurrens. These results may correlate with their differences in germination ecology which in turn depends upon phylogenetic relationships of the genus (Fay and Duke, 1977, Wogu and Ugborogho, 2000), physiological and biochemical properties of the species (Kobayashi, 2004).
Phytotoxins often inhibit cell division and expansion (Tomaszewski and Thimann, 1966), often slowdown or stop photosynthesis and change the amount of chlorophyll and respiration of plants leading to death (Batish et al. 2002). Phytotoxic potential of Lantana was more pronounced when Lantana was applied in 'higher amounts' as concentration depended growth suppression has been a characteristic of allelopathic interactions (Ashrafi et al. 2008, Inderjit and Nilsen, 2003, Randhawa et al. 2002). The present study also supports this idea as a higher 'dose' of Lantana (more concentrated extract and/or more heavier weight of residues per unit weight of paddy soil) was found to be more effective for suppression of seedling growth and development of Ludwigia species as well as for the emergence of other associated weed seeds in paddy soil. Further, our results also revealed that boiling of the extract would be more effective in suppressing germination and cotyledon expansion of Ludwigia spp. However, the reasons for such an observation cannot be explained without further investigations. Boiling the extract would have also destroyed microorganisms in the extract enabling a clear vi- 
sion of the allelopathic effects.

This work was also be in line with previous findings that crude extracts exhibit greater allelopathic effects than that produced by residues, as the visible changes are a result of reactions of different groups of chemical compounds directly leached out from tissues into the testing medium than the ones that are slowly released by decomposition to the environment (Inderjit and Callaway 2003). Compared to laboratory experiments, soil amendment experiments often interfere with chemical, physical and biological properties of soil and their dynamics in spatial and temporal scales (Bhowmik and Inderjith 2003, Inderjit 2001, Kobayashi, 2004). Therefore, visible effects of laboratory bioassays in allelopathy research may or may not always correspond with observations in either green house studies or in field (Inderjit and Nilsen, 2003). Nevertheless, the results of our laboratory study using crude extracts coincided with that of green house experiment to which crushed residues were directly incorporated, especially when higher amounts were used. However, field trials are recommended for recognizing promising results.

\section{CONCLUSION}

The study exhibited potential herbicidal effects of L. camara on Ludwigia spp. in a paddy soil medium containing rice seedlings in their early growth stage equivalent to the critical period. Additionally, it was also shown that $L$. camara does not possess toxic effect towards micro biota of paddy soil. These findings strengthen evidence for herbicidal property of L. camara and suggest its possible applications towards development of bio-herbicidal mixtures for organic paddy production in Sri Lanka.

\section{ACKNOWLEDGEMENT}

The financial assistance from National Science Foundation, Sri Lanka research grants
$\mathrm{RG} / 2005 / \mathrm{AG} / 06$ and $\mathrm{RG} / 2007 / \mathrm{AG} / 05$ is greatly appreciated.

\section{REFERENCES}

Achhireddy NR and Singh M 1984 Allelopathic effects of Lantana (Lantana camara) on Milkweedvine (Morrenia odorata). Weed Science 32: 757-761.

Ashrafi ZYS, Sadeghi H, Mashhadi R and Hassan MA 2008 Allelopathic effects of Sunflower (Helianthus annus) on germination and growth of wild Barley (Hordeum spontaneum). Journal of Agricultural Technology 4: 219-229.

Bansal GL 1998 Allelopathic effect of Lantana camara on rice and associated weeds under midhill conditions of Himachal Pradesh, India. In: Olofsdotter, M (ed), Allelopathy of Rice. International Rice Research Institute, Phillipines.

Batish DR, Singh HP, Saxena DB and Kohil RK 2002 Weed suppressing ability of parthnin, a sesquiterpene lactone from Parthenium hysterophorus. New Zealand Plant Protection 55: 218- 221.

Bhowmik PC and Inderjit 2003 Challenges and opportunities in implementing allelopathy for natural weed management. Crop Protection 22: 661-671.

Booth C 1971 Introduction of General Methods. pp 1-47, In: Booth C (ed.), Methods in Microbiology. Academic Press, London.

Carter MR and Gregorich EG 2007 Soil Sampling and method of analysis, Second edition, Canadian Society of Soil Science. pp 342-345.

Chandrasena JPNR 1988 Ludwigia decurrens Walt. A new rice field weed in Sri Lanka. Journal of National Science Council of Sri Lanka 16: 97-103.

Chaturani HGK and Ranwala SMW 2005 Phytotoxicity of Lantana camara L. (Gandapana) residues on Commelina diffusa L. (Girapala), pp 22, In: Ra- 
nasinghe $\mathrm{H}$ (ed.), Proceedings of the $25^{\text {th }}$ Annual Sessions Institute of Biology Sri Lanka.

CSIR 1966 The Wealth of India - Raw materials, Vol. VI, Council of Scientific and Industrial Research, India.

Fay PK and Duke WB 1977 An assessment of allelopathic potential in Avena germplasm. Weed Science 25: 224228.

Ghisalberti EL. 2000 Lantana camara L. (Verbenaceae), A review. Fitoterapia 71: 467-486.

Gooden B, French K, Turner PJ and Downey PO 2009 Impact threshold for an alien plant invader, Lantana camara L., on native plant communities. Biological Conservation 142: 2631-2641.

Hierro JL and Callaway RM 2003 Allelopathy and exotic plant invasion. Plant and Soil 256: 29-39.

Holm LJ, Pancho V, Herberger JP and Plucknett DL 1979 A geographical Atlas of World Weeds. John Wiley, New York, NY, USA.

Inderjit and Callaway RM 2003 Experimental designs for the study of allelopathy. Plant and Soil 256: 1-11.

Inderjit and Nilsen EK 2003 Bioassays and field studies for allelopathy in terrestrial plants: Progress and Problems. Critical Reviews in Plant Sciences 22: 221-238.

Inderjit 2001 Soil: Environmental effects on allelochemical activity. Agronomy Journal 93: 79-84.

IUCN 2001 Hundred of the World's worst invasive alien species: a selection from the global invasive species database. Invasive Species specialists group of World Conservation Union, Auckland.

Kim YO and Lee EJ 2011 Comparison of phenolic compounds and the effects of invasive and native species in East Asia support for the novel weapons hypothesis. Ecological Research 26:
87-94.

Kobayashi K 2004 Factors affecting phytotoxic activity of allelochemicals in soil - a review. Weed Biology and Management 4: 1-7.

Kong $\mathrm{CH}$, Wang PC, Zhang X, Zhang MX and $\mathrm{Hu}$ F 2006 Herbicidal potential of allelochemicals from Lantana camara against Eichhornia crassipes and the alga Microcystis aeruginosa. Weed Research 46: 290-295.

Madushani KADI and Ranwala SMW 2004 Phytotoxicity of Lantana camara L. on selected rice field weeds. pp116, In: Goonatilake H (ed.), Proceedings of the $60^{\text {th }}$ Annual Sessions. Sri Lanka Association for the Advancement of Science.

Mersie W and Singh M 1987 Allelopathic effect of Lantana camara on some agronomic crops and weeds. Plant and Soil 98: 25-30.

Murry, PR, Baron EJ, Pfaller MA, Tenover FC and Yolke RH 1995 Manual of Clinical Microbiology, $6^{\text {th }}$ edition, ASM, Washington, DC.

Narwal SS 2010 Allelopathy in ecological sustainable organic agriculture. Allelopathy Journal 25: 51-72.

Ni GY, Zhap P, Huang QQ, Hou YP, Zhou CM, Coa QP and Peng SL 2012 Exploring the novel weapons hypothesis with invasive plant species in China. Allelopathy Journal 29:199-214.

Prasad M NV 1998 Using allelopathic plants for weed control in rice. pp 27-37,.In: Olofsdotter M (ed.), Allelopathy in Rice, International Rice Research Institute, Philippines.

Qasem JR and Foy CL. 2001 Weed allelopathy; its ecological impacts and future prospects; A review. Journal of Crop Protection 4: 23-92.

Ranganath HR 1993 Use of Lantana and Mentha leaves against paddy pest moth. Journal of Andaman Science Association 9: 75-76.

Rhandawa MA, Cheema ZA and Muhammad 
AA 2002 Allelopathic effect of Sorghum water extract on germination and seedling growth of Trianthema portulacastrum. International Journal of Agriculture and Biology 4: 383384.

Roothaert R L and Franzel S 2001. Farmers preference and use of local fodder trees and shrubs in Kenya. Agroforestry Systems 52: 239-252.

Swarbrick JT, Willson BW and HannanJones MA 1998 Lantana camara L. The Biology of Australian Weeds, pp. 119-140, In: Panetta FD,. Groves RH and Shepherd RCH (eds), RG \& FJ Richardson, Melbourne.

Saha S, Pandey AK, Gompinath KA, Bhattacharaya R, Kundu S and Gupta HS 2007 Agronomy for sustainable development 37: 223-229.

Sutton DL and Potier KM 1989 Influence of allelochemicals and aqueous plant extracts on growth of duckweed. Journal of Aquatic Plant Management 27: 9095.

Tomaszewski M and Thimann KV 1966 Interactions of phenolic acids, metallic ions and chelating agents on auxininduced growth. Plant Physiology 41: 1443-1454.

Verdeguer M, Blázquez $\mathrm{MA}$ and Boira $\mathrm{H}$ 2009 Phytotoxic effects of Lantana camara, Eucalyptus camaldulensis and Eriocephalus africanus essential oils in weeds of Mediterranean summer crops. Biochemical Systematics and Ecology 37: 362-369.

WAC 1995 Data analysis of agroforestry experiments: Effect of Tithonia diversifolia and Lantana camara mulches on crop yields in farmers fields. World Agroforestry Center, Kenya.

Wadhawani C and Bhardwaja TN 1981 Effect of Lantana camara extract on fern spore germination. Celullar and Molecular Life Sciences 37: 245-246.

Wogu AR and Ugborogho E 2000 Seed morphology, germination and seedling characteristics in Ludwigia species (Onagraceae) in Nigeria as aids to identification. Seed Science and Technology 28: 657-697.

Xuan TD, Shinkichi T, Khanh TD and Chung IM 2005 Biological control of weeds and Plant Pathogens in Paddy rice by exploiting plant allelopathy: an overview, Crop Protection 24: 197206.

Zhang MX, Ling B, Kong CH, Liang GW and Dong YZ 2005 Allelopathic effect of Lantana on water hyacinth (Eichhornia crassipes (Mart.) Solms. Allelopathy Journal 15: 125-130. 